Winter 2004

\title{
The Advantages of the Civil Law Judicial Design as the Model for Emerging Legal Systems
}

Charles H. Koch, Jr

William and Mary Law School

Follow this and additional works at: https://www.repository.law.indiana.edu/ijgls

Part of the Civil Law Commons, International Law Commons, and the Judges Commons

\section{Recommended Citation}

Koch,, Charles H. Jr (2004) "The Advantages of the Civil Law Judicial Design as the Model for Emerging Legal Systems," Indiana Journal of Global Legal Studies: Vol. 11 : Iss. 1 , Article 6.

Available at: https://www.repository.law.indiana.edu/ijgls/vol11/iss1/6

This Symposium is brought to you for free and open access by the Law School Journals at Digital Repository @ Maurer Law. It has been accepted for inclusion in Indiana Journal of Global Legal Studies by an authorized editor of Digital Repository @ Maurer Law. For more information, please contact rvaughan@indiana.edu.

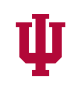

JEROME HALL LAW LIBRARY

INDIANA UNIVERSITY

Maurer School of Law
Blooming ton 


\title{
The Advantages of the Civil Law Judicial Design as the Model for Emerging Legal Systems
}

\author{
Charles H. Koch, JR.
}

Currently, a number of societies around the world are reforming their legal systems, often upon emerging from years of oppression. Two transatlantic models, the civil law and common law, will have a great influence on these reforms. For one thing, the two basic models already cover over 70 percent of the world's population in some 62 percent of the existing legal systems.' Moreover, there will be many practical, economic advantages to westernizing a legal system, which necessarily means incorporating at least some aspects of one or both transatlantic models. The key is to extract the best features of the models and adapt them to the specific legal culture. ${ }^{2}$ The civil law approach to judicial design in particular has much to recommend it. A dominant feature of the civil law model is the responsibility it places on the judge in dispute resolution. ${ }^{3}$ True, common law judges have

*Dudley W. Woodbridge Professor of Law, William \& Mary Law School. B.A., University of Maryland, 1966; J.D., George Washington University, 1969; L.L.M., University of Chicago, 1975. I would like to thank Indiana University and the participants in the symposium on Globalization, Courts, and Judicial Power sponsored by the Indiana Journal of Global Legal Studies.

1. See University of Ottawa, at http:/www.droitcivil.uottawa.ca/world-legal-systems/engmonde.html (last visited Sept. 8, 2003).

2. Comparative law commentators observe that it is possible for reformers to borrow from quite different legal systems. George N. Sfeir, Modernization of the Law in Arab States: AN Investigation into Current Civil, Criminal, and Constitutional Law in the Arab World 95 (1998) ("[Borrowing by Arab code writers] all goes to prove Alan Watson's assertion that successful borrowing could be made from a very different legal system as the law reformer looks for an idea in the foreign system which could be transformed into part of the law of his country" (citing Alan Watson, Legal Transplants and Law Reform, 92 L. Q. Rev. 79 (1976))).

3. The most often recognized distinction between the two systems is the civil law's "code" orientation and the common law's case method of evolving the law. That is, the common law judge is said to have the authority to make law and the civil law judge may only find the law from legislation. This distinction is important but subtle. As Merryman in his famous guide to the civil law for U.S. lawyers wrote:

The distinction between legislative and judicial production of law can be misleading. There is probably at least as much legislation in force in a typical American state as there is in a typical European or Latin American nation.... The authority of legislation [in the U.S.] is superior to that of judicial decisions; statutes supersede contrary judicial decisions(constitutional questions aside), but not vice versa .... If, 
more authority in the sense that they can evolve the law through precedent, whereas civil law judges do not have that authority. ${ }^{4}$ The civil law judge, however, dominates individual litigations and hence sound dispute resolution depends on the quality of its judges and on assuring that they have the wherewithal to perform their responsibilities to the best of their abilities. Thus, the lessons from civil law judicial design are particularly worthy of consideration in reforming a legal system.

Emerging legal systems should look to civil law judicial design because focusing reform on the judiciary has several advantages. Judges are important to competent dispute resolution whether the base system derives from the common law or civil law. Able judges can be the great equalizers, assuring fair litigation regardless of the relative resources of the litigants. The common law relies on the performance of its lawyers and on advocacy to assure successful litigation, but lawyers are responsible to their clients alone. Judges, on the other hand, are neutrals who are responsible to the public and ultimately justice. Furthermore, the judiciary is an identifiable and discrete component of any legal system and judicial performance and conduct can be subject to public scrutiny. Reform notions based on the common law would naturally focus on the development of a competent private bar and scrutiny of its performance, but lawyers are less identifiable and manageable as a group than judges, and formal techniques for assuring quality, as we see in the U.S., are largely ineffective.

Reference to the civil law model may have another advantage for many emerging legal systems. The role of judges in large non-transatlantic legal cultures may make the civil law judicial model more compatible with traditional customary or religiously-based legal attitudes. Judges in many of these cultures are not so much presiding officials responsible for fair litigation and choosing the winner as they are counselors, educators, or even parents charged with guiding

however, one thinks of codification not as a form but as the expression of an ideology, and if one tries to understand that ideology and why it achieves expression in code form, then one can see how it makes sense to talk about codes....

John Henry Merryman, The Civil Law Tradition: An Introduction to the Legal Systems of Western Europe and Latin America 26-27 (2d ed. 1985).

4. Id. Some suggest that common law and civil law are converging, to this Reimann observes: "Even if one were to accept that the substantive discrepancies between the civil and common law have been overrated and that the systems have been converging, there remain indisputable disparities regarding the respective conceptual tools and general structures." Mathias Reimann, Towards a European Civil Code: Why Continental Jurists Should Consult Their Transatlantic Colleagues, 73 TUL. L. Rev. 1337, 1342 (1999). 
the litigants to the proper outcome. ${ }^{5}$ That is, judges represent moral authority rather than state empowerment. The civil law judicial philosophy, which places so much faith in the judge, might be more adaptable to such legal systems. ${ }^{6}$

Recognizing the potential for judge-oriented reforms, I look here at the lessons which might be derived from civil law's approach as an "outsider," experienced with the U.S. version of the common law model. My purpose is merely to explore the advantages of civil law judicial design, not to advocate for the adoption of the whole of either model. Indeed, as will be discussed throughout, the U.S. common law system has incorporated some of these same concepts in its administrative process. ${ }^{7}$ The civil law approach might help an emerging legal culture improve the quality of its judiciary and provide it with better tools to

5. See Philip C.C. Huang, Civil Justice in China: Representation and Practice in the Qing 208 (1996) (The task was to promote harmony in society and not to allow a wayward child to spoil it. "The point was not to forgo clear-cut adjudication in favor of compromise-working, but rather to take human feeling and relations into account when considering the use of punishment, and to persuade litigants of the correctness of the court's opinion, after having come to clear-cut judgment. . based in law."); H. Patrick Glenn, Legal Traditions of the World: Sustainable DiversitY IN LAW 163 (2000) (In Islamic judging: "The law of each case is thus different from the law of every other case, and all parties, and the qadi [judge], are under an obligation of service to God to bring together the objectively determined circumstances of the case and the appropriate principles of the shari'a."). Cf. Joseph Schacht, An Introduction to Islamic Law 188-89 (1964).

6. Codification itself has certain advantages for emerging legal cultures: "Codification has also meant that the laws of the nations which have codes are readily adoptable by other nations seeking a systematic, ordered and text-based foundation for their law." Thomas GLyN Watkin, AN Historicial Introduction to Modern Civil Law 147 (1999).

7. Many of these techniques developed in U.S. administrative adjudications simply because they are more effective and often fairer in that context. Nonetheless, many of these ideas were either consciously bor rowed from the civil law or unconsciously allowed to filter into U.S. administrative processes, as demonstrable familiarity with that model legitimized non-common law thinking. In his oft-cited and highly influential article, Judge Friendly, for example, argues that the administrative process could learn from the civil law model. Henry J. Friendly, "Some Kind of Hearing," 123 U. PA. L. Rev. 1267, 1290 (1975). See generally Frank J. Goodnow, Comparative Administrative Law: An Analysis of the Administrative Systems National and Local, of the United States, England, France and Germany (The first U.S. administrative law scholar used a comparative approach in the first U.S. administrative law text.); JAMES M. Landis, ThE Administrative Process 3-5 (1938). For generations, U.S. administrative law has had available an insightful comparison with the French civil law, which is Bernard Schwartz, French Administrative Law and the Common-Law World (1954). New Jersey Chief Justice Arthur Vanderbilt wrote: "Now [Schwartz] has shown us clearly how much we can learn from the French." Id. at xvi. 
perform an active role in dispute resolution. ${ }^{8}$ My analysis below takes separately these two goals of civil law judicial design. ${ }^{9}$

\section{The Civil Law Guide to Making Better Judges}

Three aspects of the civil law judicial design might be useful for reforming a judiciary. First, the civil law uses career judges, trained and managed as such. Second, the civil law provides an active and positive approach to assuring a competent and independent judiciary. Third, the civil law's selective resort to specialized tribunals provides expert decision making where needed and, more significantly, provides a strategy for protecting the regular judiciary from compromising decision-making responsibilities.

\section{A. Professionalism}

Perhaps the most significant distinction between the civil law model and the common law model is that in the former the judiciary is a corps of specially

8. A neutral measure of people's preferences when dealing with the legal system is difficult, if not impossible. Sally Engle Merry, in a study of working-class users of courts in a Massachusetts town, describes how they go to court with feelings of legal entitlement and emerge thinking that the institution is "indifferent to the ordinary person's problem." Sally Engle Merry, Getting Justice and Getting Even: Legal Consciousness Among Working-Class Americans 170 (1990). Ordinary people in real common law courtrooms are likely to see their lawyer as engaging in ritualistic and counter-intuitive behavior which they neither control nor understand. But what would a similar study in France or Germany reveal? I have presided at a demonstration civil law trial with a French judge and observe that litigants (and other interested persons) seem to have a more congenial opportunity to "tell their story." My law students in simulated civil law proceedings found advantages. On the other hand, one empirical study purports to show that the adversarial process is preferred. See John Thibaut \& Laurens Walker, Procedural Justice: A Psychological Analysis 77 (1975). However, because its "pure inquisitorial" model is so dissimilar to the actual civil law model, it shows little more than that students prefer to make their own decisions. It does have some useful general lessons about optimum factual development which might be applied in either model. See id. at 83 .

9. This article refers to adjudications in the U.S. administrative process. Aman has argued on several occasions that U.S. administrative law principles of public participation and accountability, usually associated with its rulemaking procedures, should be employed to combat global "democracy deficit." E.g., Alfred C. Aman, Jr., Globalization, Democracy, and the Need for a New Administrative Law, 49 UCLA L. Rev. 1687 (2002). I would urge that U.S. rulemaking procedures could also enhance effective democracy "on the ground" for emerging democracies as well, but that is not the focus of this article. 
trained professionals. ${ }^{10}$ The common law does not consider judging to be a separate legal profession and hence the U.S. judiciary is staffed by "amateur" judges largely drawn from a related, but in many ways dissimilar, profession, legal advocacy. Civil law judges are educated as judges and usually serve that role throughout their professional lives. " Budding judges enter an apprenticeship as judges, not as advocates. They move from the apprenticeship supervised by senior judges, to junior positions on less important courts, to ever more important positions on more important courts. They serve within a community of judges who are available to assist them in becoming better judges. Their promotions are based on performance and are controlled by judges themselves in some form of council.

A major advantage of this design is that it necessarily creates an esprit de corps. A massive psychological literature demonstrates that people in positions of trust, including judges, tend to live up to that trust. ${ }^{12}$ Lynn Stout identified three factors that determine socially conscious behavior in judges: a tendency to do what they are told by an authority figure, a "sense of membership in a common group," and a degree of anticipation that their colleagues will cooperate. ${ }^{13}$ All of these factors are promoted, or in the case of an emerging legal system created, by the civil law judicial corps strategy.

No doubt judicial elitism has its disadvantages. Civil law judges make up an anonymous and perhaps "bloodless" elite. As Martin Vranken summarized the effect: "Judges in the civil law are civil servants who display a civil service mentality." ${ }^{14}$ Common law judges, who generally rise from practice, have been forced to deal with real world situations. The civil law system offsets the lack of

10. See Merryman, supra note 3, at 34-35.

11. See, e.g., Nigel Foster, German Legal System \& Laws 90 (2d ed. 1996) ("In Germany the judiciary is a separate career, embarked upon by professionally qualified lawyers after educational and practical legal training; it is not entered after a number of years' practice as an attorney."); Konrad Zweigert \& Hein Kötz, Introduction to Comparative Law 124 (Tony Weir trans., 3d ed. 1998) ("Judges in France, like those in Italy and Germany, are career judges; they opt for a judicial career early in life, they are appointed by the state after passing the necessary examinations, and they are generally promoted to more important positions in higher courts on the basis of their performance and years of service."). But see John Owen Haley, Authority Without Power: Law and the Japanese Paradox 106 (1991) (stating that the U.S. occupation of Japan attempted to consolidate lawyering and judging).

12. See, e.g., Lynn A. Stout, Judges as Altruistic Hierarchs, 43 W M. \& MArY L. Rev. 1605 (2002).

13. Id. at 1615-16.

14. Martin Vranken, Fundamentals of European Civil Law 62 (1997). 
practical experience somewhat with the apprenticeship program in which judges must for some time work at the "street level." Moreover, studies show that practicing U.S. lawyers, not surprisingly, bring their practice perspective with them to the bench. ${ }^{15}$ The civil law approach institutionalizes an otherworldly objectivity.

A graver danger is that this isolated and elite corps will develop its own cultural norms. Mitu Gulati and C.M.A. McCauliff demonstrate: "[T]he behavior of judges is primarily governed by internally generated norms that can be altogether different from the officially stated organizational rules." ${ }^{16}$ Studies of U.S. judges find that such "politics" in a judicial community might bias individual decisions. ${ }^{17}$ Still, these community norms have many positive effects and contribute significantly to the competence and the integrity of the judiciary. ${ }^{18}$ The key is to capture these benefits while guarding against the drawbacks. For the reasons given in the next section, the civil law judicial corps concepts might have the best chance of doing so.

15. See Gregory C. Sisk et al., Charting the Influences of the Judicial Mind: An Empirical Study of Judicial Reasoning, 73 N.Y.U. L. Rev. 1377, 1470 (1998) ("Although we initially shared [skepticism about the impact of prior employment], our study found nearly every prior employment variable of these judges, with the exception of law professors and political experience (and perhaps prosecutorial experience), to be significant in some manner.").

16. Mitu Gulati \& C.M.A. McCauliff, On Not Making Law, 61 Law \& Contemp. Probs. 157, 161 (1998).

17. See Richard L. Revesz, Environmental Regulation, Ideology, and the D.C. Circuit, 83 VA. L. Rev. 1717 (1997); Richard L. Revesz, Ideology, Collegiality, and the D.C. Circuit: A Reply to Chief Judge Harry T. Edwards, 85 VA. L. Rev. 805 (1999) (defending 1997 study of effects of ideology in judicial decisionmaking in environmental cases in the D.C. circuit from Edwards' criticism); see also Richard L. Revesz, Litigation and Settlement in the Federal Appellate Courts: Impact of Panel Selection Procedures on Ideologically Divided Court, 29 J. LEgaL Srud. 685 (2000) (examining the effects of the D.C. Circuit practice of announcing the composition of its panels before parties have prepared their briefs). While disagreeing with many of the negative implications of Revesz's work, Chief Judge Edwards seems to recognize the impact of a judicial community. See Harry T. Edwards, Collegiality and Decision Making in the D.C. Circuit, 84 VA. L. Rev. 1335 (1998) [hereinafter Collegiality and Decision Making] (criticizing the methodology and conclusions of the Revesz study, and suggesting that discussions among the judges may explain some of Revesz's results). See generally Harry T. Edwards \& Linda Elliott, Beware of Numbers (and Unsupported Claims of Judicial Bias), 80 WASH. U. L. Q. 723 (2002) (criticizing the methodology of a study which alleged anti-plaintiff bias in appellate courts).

18. Gulati \& McCauliff, supra note 16 at 169-70 ("Social sanctions in a closely knit group [such as judges] whose members repeatedly interact are likely to be highly effective. If these informal nonlegal sanctions work effectively, an expensive, formal enforcement system may be unnecessary."). Chief Judge Edwards would seem to agree with the value of community norms within a court. See Collegiality and Decision Making, supra note 17. 


\section{B. The Mechanics of Judicial Independence and Competence}

The civil law judicial design, in the context of an emerging legal system, has more potential for bringing about an independent judiciary than adoption of the U.S. judicial design. The U.S. system relies on public vetting and job security, but that strategy may not be particularly effective, especially in a legal culture with no tradition of selecting independent judges. Even in the U.S., the selection and promotion process can be extremely political and hence compromise the independence of U.S. judges. Federal judges have lifetime job security under Article III of the U.S. Constitution, but even this insulation does not seem to guarantee truly independent judging. ${ }^{19}$ More to the point, most U.S. judges do not have constitutional protections. Some 87 percent of U.S. state judges are elected and serve a term of years. ${ }^{20}$ Of course, both the appointment process and elections monitor performance, but both are inherently political. Hence, impartial judicial decision making may be compromised by the judge's concern for the political ramifications of certain decisions. Moreover, the vast majority of both federal and state adjudications, one might say the ones that really matter to most people, are carried out by so-called "legislative courts" having no constitutional protection. ${ }^{21}$ Vast numbers of adjudications are conducted by administrative judges, many of whom

19. This is true in part because it legitimizes habits of thought. See William S. Jordan, III, Judges, Ideology, and Policy in the Administrative State: Lessons from a Decade of Hard Look Remands of EPA Rules, 53 Admin. L. Rev. 45, 99 (2001) ("I would not characterize these results as demonstrating strategic ideological voting. To the contrary, as Judge Wald has argued, they appear to reflect differences in 'the personalit[ies] and life experiences that lead the judge to vote Democratic or Republican' in the first place, rather than adherence to a party or personal ideological agenda." (quoting Patricia M. Wald, Some Thoughts on Judging as Gleaned from One Hundred Years of the Harvard Law Review and Other Great Books, 100 Hanv. L. Rev. 887, 891 (1987))).

20. "Eighty-seven percent of state appellate and trial judges are selected through direct or retention elections." Nat'l Ctr. for State Courts, Call to Action: Statement of the National Summit on Improving Judicial Selection 7 (2002).

21. While Article III of the Constitution vests "judicial power" in courts constituted under its authority, Congress immediately found that all adjudications could not be conducted by these courts and created special tribunals under its legislative powers. A literal reading of the Constitution may require Congress to vest all judicial functions in Article III courts, but long tradition has validated alternative federal courts and agencies with adjudicative functions. See Richard H. Fallon, Jr., Of Legislative Courts, Administrative Agencies, and Article III, $101 \mathrm{HARv}$. L. Rev. 916, 917 (1988) (“'Article III literalism'... [is] unthinkable."). In fact, most of federal adjudications are conducted by "legislative" courts or administrative tribunals. For example, the Social Security 
have very little protection. ${ }^{22}$ The result of the U.S. system is that judges are not and perhaps cannot be insensitive to political influence. Frederick Schauer observed that U.S. judges are more driven by rational self-interest than we often concede. ${ }^{23}$ Studies show that "promotion potential is a factor in understanding lower federal court behavior." ${ }^{24}$ In short, the U.S. system has not developed an effective system for assuring impartiality and independence.

The civil law model does provide such a system. ${ }^{25}$ Civil law judges themselves control management of the judge corps. The French Constitution, for

Administration (SSA) holds hearings on about 500,000 cases a year, more than the entire federal Article III judiciary. Social Security Administration, Office of Hearings and Appeals, Key Workload Indicator Report 5 (2002), available at htrp://www.ssa.gov/policy/docs/statcomps/supplemenU 2002/2f8-2f11.pdf. While these are technically reviewed by an Article III judge, they are actually reviewed by magistrates, and Article I judges.

22. See John H. Frye III, Survey of Non-ALJ Hearing Programs in the Federal Government, 44 ADMIN. L. Rev. 261 (1992). Nonetheless, the administrative judges with no formal protection as well as those with only statutory protection generally find themselves to be independent. Charles $\mathrm{H}$. Koch, Jr., Administrative Presiding Officials Today, 46 Admin. L. Rev. 271, 278-79 (1994). I believe the survey results demonstrate that institutional norms can be an extremely effective guarantee of independence because the lack of formal protection seemed to make little difference in the perception, at least, of independence.

23. Frederick Schauer, Incentives, Reputation, and the Inglorious Determinants of Judicial Behavior, 68 U. CiN. L. Rev. 615, 620 (2000) ("In sharing this common ground of belief that what really matters to judges are their sincere policy preferences,... [legal scholars and political scientists alike] tend to ignore or downplay the possibility that judges, no less than legislators and bureaucrats, have strong career-based self-interests that often inform or dominate their policy preferences."). A study has shown that the Supreme Court is conscious of political actors in setting its agenda. See Lee Epstein et al., Dynamic Agenda-Setting on the United States Supreme Court: An Empirical Assessment, $39 \mathrm{HARv}$. J. on Legis. 395, 403 (2002) ("Our analysis of the data leads us to conclude that the justices do indeed consider the preferences and likely responses of other political actors in deciding whether to grant certiorari."). But see Richard A. Posner, What Do Judges and Justices Maximize? (The Same Thing Everybody Else Does), 3 Sup. Ct. Econ. Rev. 1, 2 (1993) ("The economic analyst has a model of how criminals and contract parties, injurers and accident victims, parents and spouses-even legislators, and executive officials such as prosecutors-act, but falters when asked to produce a model of how judges act."); Edward Rubin, The New Legal Process, The Synthesis of Discourse, and the Microanalysis of Institutions, 109 Harv. L. Rev. 1393, 1399 (1996) ("[N]o stable [rational choice] theory has emerged to explain the behavior of judges ....").

24. Sisk et al., supra note 15, at 1493 (citing Mark Cohen, Explaining Judicial Behavior of What's 'Unconstitutional' about the Sentencing Commission?, 7 J.L. Econ. \& ORG. 183, 193 (1991)).

25. Civil law judges also have life tenure. See, e.g., LA Constitution, art. 64, translated in Constitutions of the Countries of the World: France 19 (Gisbert H. Flanz, ed., Oceana Publications 2000) ("Judges are irremovable."); Foster, supra note 11, at 90-91 ("Judges are guaranteed complete independence... Judges cannot be sacked unless it is by judicial order following a judicial hearing."). 
example, establishes a disciplinary body dominated by judges. ${ }^{26}$ That is, the judiciary itself controls promotion and assignment. ${ }^{27}$ In contrast, the U.S. judiciary can only engage in negative management, disciplining judges whose conduct is so egregious that it cannor be allowed to continue. The civil law system allows the judicial authorities to provide positive incentives and mentoring, as well as discipline. Emerging legal systems should adopt this approach and constitute a self-governing judicial body. Such a closed system is not without dangers, as suggested above, but potential shortcomings can be controlled by transparency and process. $^{28}$

Many U.S. state administrative judiciaries are adopting a more management-oriented approach to their judges. These states bring administrative judges together into one administrative unit, usually called a "central panel," from which individual agencies request judges. ${ }^{29}$ This approach captures much of the same advantages as the civil law model in monitoring and motivating optimum judicial performance, while at the same time protecting judges from external forces. ${ }^{30}$ In short, a self-managed judiciary has suggested its advantages in the United States, and its adoption demonstrates that it can be incorporated into a common law setting.

Common lawyers might argue that judicial self-management in the civil law system dangerously consolidates authority and hence increases the opportunity

26. La Constiturion, art. 65 , in Constitutions of the Colntries of the World, supra note 25 , at 19.

27. See John Bell et al., Principles of French Law 64 (1998) ("Since promotion is central to the career of all judges, its organization is all the more relevant and must be strictly regulated.").

28. The danger is that the judicial elite will themselves distort judging. See J. Mark Ramseyer \& Minoru Nakazato, Japanese Law: An Economic Approach 17 (1999) ("This institutional structure radically shapes the incentives judges face: fundamentally it gives judges an incentive to act in those ways that the people deciding their transfers consider appropriate.").

29. Flanagan identified twenty-five states and at least three major cities. James F. Flanagan, Redefining the Role of the State Administrative Law Judge: Central Panels and Their Impact on State ALJ Authority and Standards of Agency Review, 54 Admin. L. Rev. 1355, 1357 (2002). This approach has been proposed for federal adjudications for years. See e.g., Antonin Scalia, The ALJ Fiasco-A Reprise, 47 U. CHI. L. Rev. 57, 79 (1979) (“The problem of improper influence would also be solved by implementing proposals for establishment of a unified ALJ corps, headed by an independent administrator."). For several reasons, the unified panel has not been adopted in the federal system. See Paul Verkuil et al., The Federal Administrative Judiciary 171-74 (1992).

30. See John W. Hardwicke, The Central Panel Movement: A Work in Progress, 53 Admin. L. Rev. $419,425-27$ (2001). 
for corruption. Examples of corruption in civil law systems are not scarce. ${ }^{31}$ The adversarial process in the common law system, by contrast, relies on the lawyers and judges to check each other. The many examples of this system breaking down demonstrate that this guarantee is not flawless. ${ }^{32}$ The judges in any system may be corrupted. The search is for the optimum mechanism for preventing corruption, especially in systems without a positive tradition. The judge-managed civil law system might be better able to accomplish that.

\section{Assuring Competence and Independence in the Litigation Itself}

The civil law system extends this self-regulation of judicial performance into litigation itself. The civil law process utilizes several judges, some to build the record, others to manage the litigation, and others to bring the case to a decision. For most significant litigation, both civil and criminal, the judges sit in panels. ${ }^{33}$ So the civil law system, with several judges involved, creates numerous whistleblowing opportunities. The threat of whistleblowing itself assures some

31. See Edgardo Buscaglia, An Analysis of Corrupt Practices Within the Judiciary in Latin America, in Essays in Law and Economics IV 223, 234 (Claus Ott \& George Von Wangenhem eds., 1998) (" $[C]$ orruption runs rampant within the judiciary.... [T] the overall social system are extremely pernicious."). Nagle, herself a former Colombian judge, writes: "In Latin America, corruption is so intensely woven in the fabric of government that accountability to the people is of almost no consequence .... Furthermore, there is little historical precedent for judicial activism and independence. These are concepts foreign to the legal traditions of the civil law system, and particularly to the civil law systems of Latin American." Luz Estella Nagle, The Cinderella of Government: Judicial Reform in Latin America, 30 CAL. W. INT'L L. J. 345, 370 (2000). Those from other civil law systems might contest the verdict on independence although a certain type of judicial activism is foreign (literally) to the civil law philosophy. It should be noted that Latin American systems are increasingly a mix of the civil law and common law models so that lacking the institutionalized norms of an elite corps it is also without the imbued constraints of the judicial tradition of established common law systems. Again it is a question of which is more easily created in a system with neither.

32. For example, a study prepared for the National Commission on Judicial Discipline and Removal found numerous cases of resignations and several impeachments for corruption. EMILY Field Van Tassel, Why Judges Resign: Influence on Federal Judicial Service, 1789 to 1992, at 17 (1993), available at http:/www.fjc.gov/public/pdf.nsf/ookup/judgeres.pdf/\$File/judgeres.pdf ("The rate of judicial departures following allegations of misbehavior is much higher than either the impeachment or the conviction rate [because judges usually resign rather than face such allegations]."). See, e.g., Nixon v. United States, 506 U.S. 224 (1993).

33. See Andrew West et al., The French Legal System 77, 83 (2d ed. 1998). 
level of integrity. ${ }^{34}$ Collegiality creates incentives for acting within the institutional norms and a deterrent against judges who might be tempted. The U.S. system depends on the practicing bar to police judicial corruption at the trial level. A system in which the judges, as well as lawyers, police the judiciary seems more likely to guarantee a degree of judicial integrity.

The civil law model is also more likely to alleviate innocent cognitive biases. An empirical study found that judges (like everyone else in daily life) use heuristics in judicial decision making. ${ }^{35}$ Heuristics are mental shortcuts which are useful, but can produce systematic errors, or "cognitive illusions." The most potent device for correcting these errors is training in decision making. ${ }^{36}$ The long training and experience of civil law judges as fact finders and decision makers will better serve this purpose, although the common law system could no doubt educate its judges about these dangers once they reach the bench. Civil law use of collegial judicial decision making can also combat cognitive illusions. ${ }^{37}$

\section{Special Courts and the Implications for Judging}

Established civil law systems have detached certain tasks and created specialized court systems to deal with them. The Germans, for example, have five separate court systems, only one of which is a general law court, and a constitutional court. ${ }^{38}$ The French also have special courts. ${ }^{39}$ The U.S. scheme generally avoids specialist courts for reasons that might be ir relevant to an emerging legal system. ${ }^{40}$ The adoption of separate specialized court systems by an emerging legal system

34. Frank Cross \& Emerson Tiller, Judicial Partisanship and Obedience to Legal Doctrine: Whistleblowing on the Federal Courts of Appeals, 107 YALE L. J. 2155, 2174 (1998) ("In short, on multi-judge panels, the minority judge can serve as a whistleblower by revealing these biasing cognitive shortcuts. Once the majority can no longer readily rationalize its decision under the legal model, it will frequently concede to the commands of that model.").

35. Chris Guthrie et al., Inside the Judicial Mind, 86 Connell L. Rev. 777, 805-11 (2001).

36. See id. at 821 ("J]udges might learn to educate themselves about cognitive illusions so that they can try to avoid the errors that these illusions tend to produce.").

37. See id. at 826-27.

38. See Anke Freckmann \& Thomas Wegerich, The German Legal System 129 (1999) ("Each of these jurisdictions is headed by a Federal Court as the highest court of the Federation and as the court of last resort.").

39. See WEst, supra note 33, at 76-81.

40. See Richard L. Revesz, Specialized Courts and the Administrative Lawmaking System, 138 U. PA. L. Rev. 1111 (1990). 
might enhance expert dispute resolution, protect the customary courts, and insulate the regular judiciary from tasks that are considered inappropriate.

One reason for specialization is to make the best use of expertise. Specialist courts increase judicial expertise and probably reach more objective judgments based on technical considerations. Such specialization might recommend itself to societies in which technical human resources are in short supply, especially among those persons who might participate in litigation. In those cases in which the U.S. system uses expert tribunals, usually administrative agencies, their decisions are ultimately reviewed by a generalist court. ${ }^{41}$ U.S. legal culture finds benefit in at some point having the experts justify themselves to non-experts. ${ }^{42} \mathrm{In}$ this regard, an emerging legal system might choose between the two strategies depending on the desired dominance of expert decisionmaking.

A second reason emerging legal systems might establish specialized courts is the protection of the indigenous legal culture. Certain courts may be and often have been created to assure foreign interests a "modern" forum for their brand of conflict, e.g. finance or commerce, and yet the society may continue its indigenous legal tradition in alternative tribunals. A developing society could isolate its "modernization" concession by adopting special court systems, with special jurisdiction, procedures, and expertise. ${ }^{43}$ Those courts can be separated from the courts that are culturally sensitive and expert in the customary laws.

Reforming legal systems may consider the third reason civil law systems have created special courts. Underlying the civil law philosophy is a fear of assigning social policy to the judiciary. Indeed, much of the division between the civil law and common law results from different perceptions of the courts and the relationship between courts and the "democratic" institutions of government. Simply put, the common law grew out of distrust of majorities, while the civil law reflects a distrust of elitist courts. ${ }^{44}$ Civil law jurisprudence generally,

41. The only exception in the federal system is the Federal Circuit which has subject matter, rather than geographic, jurisdiction to review certain specialized tribunals and even its decisions may be reviewed by the generalist Supreme Court. Also, review of administrative expert judgments is often limited and sometimes precluded. 3 Charles $\mathrm{H}$. Косн, Jr., Administrative Law and Practice, §§ 9.2[4], 13.1 (2d ed. 1997).

42. See Fallon, supra note 21, at 917.

43. Civil law systems, for example, have special commercial courts. RaYmond Youngs, English, French \& German Comparative Law 80 (1998).

44. See VRANKEN, supra note 14 , at 63 ("[O]n the Continent a narrow reading of statutes was advocated out of distrust for the judiciary, whereas in the common law any distrust tended to be directed towards the legislature who was perceived to be encroaching upon the court's territory."). 
although not universally, grew out of experience that suggests that courts can do at least as much damage as any other institution of government. Fear of the judiciary created the instincts behind the commitment to statutory language and prohibition against judicial law making. ${ }^{45}$ Many emerging democracies have experienced the abuse and excesses of the judiciary and hence are drawn to methods that limit its interference in social policy. ${ }^{46}$

Nonetheless, modern societies need tribunals with law-making responsibility, and the civil law satisfies this need without ceding too much authority to the judiciary by granting limited authority to courts designed for the purpose. The specialist court schemes empower some judicial forays into social policy while

45. The relevance of a code system for our discussion of the judiciary is the enthusiastic denial of judicial law-making power. John P. Dawson, The Oracles of the Law 431 (1968) ("The chief legacy of the [French] Revolution was not judicial submission to the disciplines of the codes but a deep-seated, widely-held conviction that judges lacked lawmaking power."). By confining law making to the legislature, a code regime confines judicial discretion. See Rene David \& John Brierley, Major Legal Systems of the World Today: An Introduction to the Comparative Study of THE Law 134-35 (3d ed. 1985). The common law system sees judge-made law as the real law. See Henry Hart, Jr. \& Albert Sacks, The Legal Process: Basic Problems in the Making and Application of Law 163-64 (William N. Eskridge, Jr. \& Philip P. Frickey eds., 1994) ("The body of decisional law announced by the courts in the disposition of these [individual] problems tends al ways to be the initial and continues to be the underlying body of law governing the society."). While common law systems have many codes, the civil law commitment to codes expresses a commitment to language which is not present in the United States. Still, the common law progenitor British judges are confined by the notion of "parliamentary sovereignty." SIR WILLIAM WADE \& Christopher Forsyth, Administrative Law 29 (7th ed. 1994) ("The sovereignty of Parliament is a peculiar feature of the British constitution which exerts a constant and powerful influence. In particular, it is an ever-present threat to the position of the courts; and it naturally inclines the judges towards caution in their attitude to the executive, since Parliament is effectively under the executive's control.").

46. See, e.g., T'ung-tsu Ch'ü, Local Government in China under the Ch'ing 14-35 (1962). "In short, it is no exaggeration to say that the local administration was in the hands of magistrates." Id. at 14. "[The gentry] and the local officials together determined the local policy and administration and shared the control of society.... This stability was threatened only when the dissatisfaction of the people was intense enough to culminate in open revolt." Id. at 198-99. See also Philip C.C. Huang, Code, Custom, and Legal Practice in China 15-16 (2001) (describing Chinese drafting of new civil and criminal codes based on the German code); George N. Sfeir, Modernization of the Law in Arab States: An Investigation into Current Civil, Criminal, and Constitutional Law in the Arab World 23-50 (1998) (noting, however, that this shift might have been because the existing courts were just incapable of dealing with the needs of a modern, liberal state rather than that they were the instruments of oppression); NATHAN J. Brown, The Rule of Law in the Arab World: Courts in Egypt and the Gulf 15 (1997) (giving as examples of the use of courts as instruments of oppression: Israeli occupation, South African apartheid, Nazi Germany, and Allende's Chile). 
generally protecting democracy from a closed judiciary. Based on the German model, civil law systems tend to have a constitutional court separated from those courts handling regular legal business. ${ }^{47}$ Thereby, civil law systems satisfy the need for constitutional review of the legislature. ${ }^{48}$ Similarly, many civil law systems have separate administrative courts to handle suits against the government, which necessarily raise sensitive policy issues. ${ }^{49}$

In addition to confining judicial authority, the specialist court strategy also protects the regular judiciary from the taint of engaging in political and policy, sensitive controversies. The United States assigns almost all types of issues to one judiciary. The U.S. experience might show emerging legal systems the value of insulating its judiciary from certain types of issues. The separation between legal responsibility and law making in courts dealing with value-laden societal issues might have advantages for establishing the credibility of a new judiciary.

\section{The Civil Law Guide to Making Judges More Effective at Dispute Resolution}

The judge's role in civil law litigation provides the second group of valuable lessons for emerging legal systems. Judicial control of dispute resolution is the hallmark of the civil law system. The European Court of Justice (ECJ) of the European Union (EU) provides a multi-cultural example of the work of judges in a civil law-rooted process. ${ }^{50}$ After the pleading stage, the parties' control virtually ends and the court takes over. A special judicial officer is assigned the case and serves as a "judge-rapporteur," responsible for building the record. Like all

47. See WATKIN, supra note 6, at 6 ("Another hallmark of civil law systems therefore is their possession of a constitutional court or some such body to hear and determine [whether a particular piece of legislation offends against the fundamental law of the state].").

48. See Louis Favoreu, Constitutional. Courts 4-12 (Alavin A. Levasseur et. al. trans., 2001).

49. See Watkin, supra note 6, at 370 ("Most civilian countries have separate administrative courts to deal with matters of administrative law...."). See also Schwartz, supra note 7, at 11 ("[Council of State's (highest French administrative court)] decisions were swayed just as much by policy as by law."); Jurgen Schwarze, European Administrative Law 9 (1992) (noting the parallel between the French Council of State and the European Court of Justice whose decisions also have "considerable political repercussions").

50. However, the ECJ's procedures were largely modeled after the French Council of State, the highest administrative court. See L. Neville Brown \& John S. Bell, French Administrative Law 266-67 (4th ed. 1993). 
civil law courts, the ECJ runs the investigation through the rapporteur and has available its own expert advice. The rapporteur's report will serve as the basis for a decision. Before the Court itself considers the case, an independent judicial officer, the "Advocate General," prepares an opinion to "assist" the Court." Although the extent to which the court adopts the advocate general's opinion may vary, the report is always extremely important. ${ }^{52}$ Thus, the judiciary controls fact gathering and obtains independent expert advice, legal and otherwise.

Perhaps led by the civil law system, the U.S. system incorporates similar notions in the design of administrative adjudications. ${ }^{53}$ The U.S. administrative process also often places considerable responsibility on the administrative judiciary and provides it with similar tools to carry out that responsibility. These accommodations to an active administrative judiciary are noted below to demonstrate the advantages of these concepts and that they can exist and perhaps selectively improve adjudication within the common law tradition.

The civil law process has developed several useful procedural strategies to allow the judiciary to carry out its active role. ${ }^{54}$ First, the civil law makes the judges responsible for the adequacy of the decisional foundation, the "record." Second, and related, civil law judges manage the development of a continuing process whereby the body of information develops over time rather than at a single event, the trial. This process also captures the advantages of a mix of written and oral presentation. Third, the civil law process assures judges access to their own expert advice and counsel. Fourth, the civil law process is designed for judicial decision making. Let us look at the value of these strategies, particularly for reform of an emerging legal system.

51. See Consolidated Version of the Treaty Establishing the European Community, Mar. 25, 1957, 2002 O.J. (C 325) 123; L. Neville Brown \& Tom Kennedy, The Court of Justice of the European Communities 64 (5th ed. 2000) ("His title ... is something of a misnomer, since he is really no more an advocate than he is a general. On the contrary, he is a member of the Court.") (Internal citation omitted).

52. Anthony Arnull observed: "[M]ost students of the Court would probably say that it is fairly unusual-although by no means unheard of-for the Court to depart from the Opinion of its Advocate General and there are reasons for believing that, whether or not an Opinion is followed, the Judges find it helpful." Anthony Arnull, The European Union and its Court of Justice 8 (1999).

53. Administrative law advocates a procedural flexibility which allows it to escape the dogma of traditional Anglo-American procedures and an eclecticism that allows it to incorporate useful alternatives from other legal cultures. See Aman, supra note 9, at 1715.

54. Not "activist" in U.S. terms, common law judges have considerable law-making power, which can be exercised to the point of creating extremely active lawmakers. Civil law judges are not to make law, but some perform their "interpretive" function in an activist way. 
First, the civil law court is responsible for an adequate record. ${ }^{55}$ In both criminal and civil proceedings, various judges contribute to the record and the president of the court assures that the record is complete before it goes to the decisional stage. The fact gathering, as well as fact finding, responsibility of the civil law judge has much to recommend it to developing nations attempting to improve their litigation processes. The civil law makes the public assume much of the cost of litigation. This approach might be essential to legal systems in which the litigants are likely to have little to spare for dispute resolution. Judicial control can make the fact gathering affirmatively objective. In contrast, the common law judge acts negatively to prevent the introduction of certain types of information at the trial stage, with this decision often determined by formalistic rules. By making the development of the record, in essence, a public commitment, the civil law judicial system makes litigants' resources, representatives, and conduct less important to a fair result.

The U.S. administrative process often places the responsibility for an adequate record on the government. In many programs, U.S. administrative law judges (ALJs) must actively assure an adequate record and that approach has been consistently affirmed. ${ }^{56}$ The Social Security Administration (SSA), a classic example, relies on its ALJs to assure an adequate record..$^{57}$ The claimant in an SSA case is not always represented, and in those cases the judge must assure that the claimant's case is sufficiently developed. Responsibility for developing the record for a denial of SSA benefits rests with the ALJ because no participant in the hearing opposes the grant. ${ }^{58}$ This system is often criticized by adherents to the adversary process, but it merely adopts a different vision of the role of the judge, one consistent with the civil law process. Indeed, one effort to build-in

55. In contrast, the common law process does not hold the judges responsible for a complete record. See Model Code of Judicial Conduct Cannon 3B(7) cmt. (2000) (“A judge must not independently investigate facts in a case and must consider only the evidence presented."); see JEFFrEY Shaman et al., Judicial Conduct and Ethics 172 (3d ed. 2000) ("Unlike the European system, in which judges have the primary responsibility for the development of litigative facts, American judges are generally permitted only to consider the evidence and testimony that is produced by counsel.").

56. $2 \mathrm{KocH}$, supra note 41, \$5.25[2], at 70 .

57. The vast majority of these cases involve challenges to the denial of disability benefits under either the federal insurance program or need-based welfare.

58. The denial is sometimes characterized as the agency's position, but the agency was established to pay the benefits, so its position is much like that of the judges: to make sure the claimant should get the benefits. 
adversariness by having someone represent the denial was a failure. ${ }^{59}$ However, in a civil law vein, one recent study suggested that ALJs use "counselors," whose responsibility would be to assist the judge in assuring a complete record. ${ }^{60}$

Second, the civil law record is developed over time; its development is truly a "process." While there is an oral trial at the end, much of formal evidence is gathered and made part of the record prior to the oral proceeding. The oral proceeding is quite abbreviated, largely confined to tying up loose ends and reaching a decision. The common law "pre-trial" is just that, merely preparation for the trial in which all information is presented and the decision is reached. Logistically, the civil law process seems preferable in a context in which few resources are available for litigation. A major advantage is that the parties can better manage the scheduling of much of the record building. Indeed, a preparatory judge might go to the witnesses to develop evidence rather than requiring them to be present at a particular time (usually inconvenient) and place (to which transportation may be difficult). The extended record building might also take better advantage of scarce attorney time in systems just developing their corps of private litigators. The dossiers are constantly available so that a lawyer can manage review of the evidence more efficiently. Moreover, lawyers can review the growing record during the course of the investigation and can recommend that the judge seek additional evidence, request experts or different experts, question other witnesses, or further examine those witnesses questioned.

59. The SSA admitted failure and ended the project. Federal Old-Age, Survivors, and Disability Insurance; Supplemental Security Income for the Aged, Blind, and Disabled; Discontinuance of the SSA Representation Project, 52 Fed. Reg. 17,285 (May 7, 1987) (to be codified at 20 C.F.R. pts. 404 and 416). Its explanation was unhelpful, but a U.S. district court, enjoining it, observed: "Has the quality of the hearing dispositions improved? The answer... has to be a resounding no." Salling v. Bowen, 641 F. Supp. 1046, 1062 (W.D. Va. 1986).

60 . In a study commissioned by the Social Security Advisory Board, three administrative law scholars concluded:

Given the potential downsides of introducing or experimenting with the adversary process in this setting and our judgment that such a step would fail to advance the crucial need to improve the record development process, we conclude that the best SSA "representative" would be a non-adversary Counselor who could help provide the ALJ with a timely and complete record for decision.

Frank Bloch et al., Introducing Nonadversarial Government Representatives to Improve the Record for Decision in Social Security Disability Adjudications 73-74 (2003) (report on file with the author). 
This process leads to a decision based largely on a written record. The reliance on written materials makes the proceeding less burdensome for the lawyers, parties, and witnesses. It provides the judge with an opportunity to engage in more thoughtful consideration. Indeed, while such written procedures might be inconsistent with common law philosophy, U.S. administrative law often captures these same advantages.$^{61}$ Also, writing, as the administrative process has shown, is far superior for introducing expert-type evidence. Even in developing countries, litigation is likely to revolve around expert information, e.g. medical, engineering, or even custom and usage information. The more efficient the gathering of that evidence the better.

The civil law written process facilitates correction of mistakes of fact and law. Reliance on written records allows the civil law system to engage in de novo review of lower court judgments. ${ }^{62}$ In an emerging legal system in which the breadth of judicial expertise is likely to be thin, this de novo review would promote consistency and accuracy as well as integrity. The U.S. administrative process uses the same techniques, so that administrative appellate authorities generally have authority to substitute judgment on both law and fact. ${ }^{63}$ As in the civil law system, acceptance of a written record validates substitution of judgment

61. Broad discretion to incorporate written procedures was confirmed by the U.S. Supreme Court. See Weinberger v. Hynson, Westcott \& Dunning, Inc., 412 U.S. 609, 620-21 (1973) (approving the use of written procedures even when the statute seems to require an oral hearing); see also Hoyl v. Babbitt, 129 F.3d 1377, 1386 (10th Cir. 1997) (explaining that a written hearing may satisfy procedural due process under the U.S. Constitution). Increased use of written materials may be making its way into English courts. See T.H. Bingham, "There is a World Elsewhere": The Changing Perspectives of English Law, 41 InT'L \& Comp. L.Q. 513, 526 (1992) (speaking of the increased use of written materials: "[I]f a judge of (say) the immediate post-war period were to return to the courts today, whether at first instance or on appeal, he would feel himself to be in an environment that would feel quite strange and, as he might think, un-English.").

62. See VRanken, supra note 14, at 59. The Supreme Court of Cassation, the highest French court, is not strictly a court of appeals because it only reexamines points of law and it may not revise decisions as a court of appeals would. See Christian Dadomo \& Susan Farran, The French Legal System 189 (2d ed. 1996).

63. Traditionally, administrative appellate review is de novo. The U.S. Administrative Procedure Act (APA), the statute which sets general procedural norms for all federal agencies, codifies this tradition when it provides: "On appeal from or review of the initial decision, the agency has all the powers which it would have in making the initial decision ...." 5 U.S.C. \$ 557(b) (2000). However, some administrative schemes, particularly in the states, impose more limited review. See generally Jim Rossi, Overcoming Parochialism: State Administrative Procedures and Institutional Design, 53 Admin. L. Rev. 551 (2001). 
for that of the presiding official who actually heard the testimony. ${ }^{64}$ The administrative process, like the civil law model, finds that values of consistency and equality of treatment justify independent fact finding by a review tribunal. ${ }^{65}$

Third, the civil law gives its judges the assistance they need to fulfill their extensive responsibility. The civil law judge, for one thing, has control over and use of expert information. The judge identifies the experts and their loyalty is to the court. ${ }^{66}$ The parties can monitor judicial conduct because a lawyer who disagrees with an expert may request another expert. The system polices the judge here by making denial of this request the only one subject to what in the U.S. would be called interlocutory appeal, appeal before the trial. ${ }^{67}$ The publicly financed expert scheme is another way the civil law system levels any inequality in litigant resources. ${ }^{68}$ Given the relatively scarce expertise in developing societies, a party's ability to husband the available experts may be particularly damaging to fair dispute resolution.

Again, the argument that this process would violate some fundamental common law principles can be met by reference to the U.S. administrative process. Admittedly, judges in the U.S. system are not allowed to consult their own

64. That the one who hears the witness is best able to evaluate the testimony is a fundamental assumption of the common law. However, this assumption may not be supportable in fact. See Olin Guy Wellborn, Demeanor, 76 Cornell L. Rev. 1075 (1991); see also Jeremy A. Blumenthal, $A$ Wipe of the Hands, A Lick of the Lips: The Validity of Demeanor Evidence in Assessing Witness Credibility, 72 NEB. L. Rev. 1157, 1159 (1993) ("Social scientists have thus effectively subjected to empirical trial the validity of ... demeanor evidence [in judging credibility]. Surprisingly, successive testing of this 'fundamental' legal precept has repeatedly demonstrated its fallacy.").

65. In fact, although substitution of judgment on facts by a review authority is felt incompatible with the common law trial, the U.S. Constitution states that, in some instances, the Supreme Court "shall have appellate Jurisdiction, both as to Law and Fact ...." U.S. Const. art. III, § 2, cl. 2 (emphasis added).

66. See Catherine Elliott \& Catherine Vernon, French Legal System 129-30 (2000) ("The judge's powers concerning oral evidence are very wide.... The French judge has even greater powers in connection with expert evidence, as the normal practice is for a single neutral expert appointed by the court. Parties do not normally appoint their own experts."); see also West ET AL., supra note 33, at 297 ("It is for the judge to choose the expert ....").

67. See WEST ET AL., supra note 33, at 297.

68. Parties are ultimately billed for the cost of the expert. Still, there is a savings in that they need only pay for experts sufficient to satisfy the judge rather than redundant experts to counteract their opponents' experts. Moreover, a reforming system might consider public financing. 
experts. ${ }^{69}$ However, the administrative process takes a more liberal approach to supplying judges with expertise. If providing judges with expert assistants might improve the quality of a developing litigation system, administrative law shows that such a system does not necessarily violate common law principles, such as the ex parte doctrine. ${ }^{70}$

The civil law scheme may also provide its judges with experts in decision making, as well as record building. Those tribunals in which law making is permissible, such as constitutional courts or the French Council of State, are supplied with judicial officers whose duty is to advise the court. The EU supplies the most universally recognized example, the advocate general, but this institution was modeled after similar judicial advisors in the French system. ${ }^{11}$ Nothing similar to the advocate general type of jurist exists in the U.S. system, but much recommends it to emerging legal systems that are developing their laws. ${ }^{72}$ An advising judicial officer like the EU's advocate general may be beneficial in an emerging legal system in which the quality of the judges may be quite varied. Moreover, many developing countries have a need to assure representation of various groups on their lawmaking tribunals, and an advising judge can add uniformity and objectivity, as well as expertise, where the primary judges are selected more for their affiliation than their judicial competence.

Fourth, the civil law system is designed around judicial decision-making responsibility. Again, this concept would seem inconsistent with the common law procedure designed around the jury. The common law procedure envisions the judge as a gatekeeper protecting the lay jury by enforcing certain rules that

69. Under the Model Code of Judicial Conduct, judges may seek legal advice only. MODEL Code of Judictal Conduct, supra note 55, at Canon 3B(7). See also Shaman et AL., supra note 55, at 173 ("While judges may, under certain circumstances, obtain expert advice concerning the law from disinterested legal experts, the exception does not extend to experts in other areas.").

70. The Federal Administrative Procedures Act (APA), which covers all U.S. agencies, prohibits ex parte communication with an "interested person" only. 5 U.S.C. $\$ 557$ (d) (2000).

71. "Their function has no parallel in the English legal system, though it is similar to that of a commissaire du gouvernement in the French Conseil d'Etat." T.C. Hartley, The Foundations of European Community Law 55 (1998). The French "government commissioner" advises the adjudicating arm of the Council of State and is not, as the title implies, a representative of the government.

72. The Model Code of Judicial Conduct does provide a very narrow concession to consultation with legal experts. Model Code of Judicial Conduct, supra note 55, at Canon 3B(7)(b) ("A judge may obtain the advice of a disinterested expert on the law ... if the judge gives notice to the parties of the person consulted and the substance of the advice, and affords the parties a reasonable opportunity to respond."). 
assure the quality of the record. In fact, most U.S. cases, both civil and criminal, do not involve juries. ${ }^{73}$ In addition, administrative adjudications provide for decisions by the administrative judge, even in proceedings that are very nearly criminal. ${ }^{74}$ Still, the common law concept is that the trial should be designed to accommodate a jury decision. In contrast, the civil law system is designed for decision by judges. As we have seen, this affects record building and the tools given the judge.

It also affects the judging. Most important cases are decided by a panel of judges. ${ }^{75}$ Thus, where the decision is likely made by judges, the collegial checking and other decisional techniques (e.g. junior judges speak first, assuring some independence from their seniors) assures more integrity and perhaps competence especially where competent judges themselves are in short supply. Indeed, this panel approach educates judges as well, and hence provides the system with experienced judges without litigants paying the price for judicial apprenticeships.

Another advantage of the civil law approach, which would nonetheless suggest itself even to common law systems, is that judges are trained to make decisions. Common law judges "graduate" from litigation. They are trained as litigators. This training does prepare them to run the proceeding. However, they are not trained, experienced, or often psychologically prepared to serve as decision makers. Judicial training and selection in civil law systems recognizes that they are not only record guardians, but also decision makers. A significant part of their training and experience is designed to make them sound decision makers. An emerging system, either civil or common law (or the United States), might consider training and mentoring designed to make judges good decision makers.

73. In the U.S., about $5 \%$ of the felony cases and about $1 \%$ of the civil cases reach a jury. See Jeffrey Abramson, We, the Jury: The Jury System and the Ideal of Democracy 252 (2000).

74. Many U.S. agencies have the authority to order "civil penalties," which although technically not criminal, are not easily distinguishable from fines which are. See, e.g., Noriega-Perez v. United States, 179 F.3d 1 166, 1172 (9th Cir. 1999) (following Hudson v. United States, 522 U.S. 93 (1997) (involving double jeopardy.)); $c f$., 15 U.S.C. $\S 45(1)$ (1997) (authorizing the Federal Trade Commission to order civil penalties). In New York, traffic violations may be heard in administrative adjudications. N.Y. State A.P.A $\S 102.3$ (McKinney 1995).

75. In France, major crimes are judged by a jury composed of nine lay jurors and three judges. WEST ET AL., supra note 33, at 236. 


\section{Conclusion}

The common law and the civil law models likely will dominate the development of a global legal culture, at least in its first iteration. ${ }^{76}$ In turn, this global legal culture will affect national law and legal institutions, especially in emerging legal systems. Many legal cultures are looking to the transatlantic models for guidance in reforming and modernizing their legal systems.

Focusing on better judges and judging has much to recommend it to these cultures. Many of these cultures already have in place some version of the civil law models, others have borrowed from the common law model, and still others retain their customary or religious legal systems, or those systems in practice dominate over the borrowed scheme. In all of these, the judge is the key to improving their legal system. Since the civil law is judge-oriented, it has many lessons for reformers around the world. As I am a common lawyer, there seems to be some value in my identification of the potential benefits of the "competing" model. As a U.S. administrative law specialist, it seems useful that I identify instances in which the U.S. common law model has captured some of those advantages in its administrative adjudications. These advantages then may be universal and appropriate reform options for any legal culture. The key then is political will.

76. Charles H. Koch, Jr., Envisioning a Global Legal Culture, 24 Mich. J. of INT'L L. (forthcoming Fall 2003). 